\title{
Analysis of the Factors Influencing Bulgaria-China Trade Competitiveness Index before and after Bulgaria's Accession to the European Union
}

\author{
Kameliya FAM ${ }^{1}$ \\ ${ }^{1}$ Shanghai University, Shangda Rd 99, Shanghai, China \\ *Kameliya Fam
}

Keywords: Bulgaria-China trade, Trade competitiveness index, Import, Export, OLS.

\begin{abstract}
In this study, we want to examine the impact a small economy, such as Bulgaria, has when in the middle of two economic powers like China and the European Union (EU). We propose an OLS model to determine the factors which influence Bulgaria-China trade competitiveness index (TCI) for several groups manufactured goods and how Bulgaria's accession to the European Union affected them. The conducted study showed Bulgaria's stable and strong currency and low inflation rate have a positive impact on trade with China while the slow economic growth and unsteady economic situation prevents the bilateral trade from further development. According to our finding, the accession to the EU has a promoting but weaker than expected effect on Bulgaria-China trade competitiveness index. The results indicated, for an improved trade relationship with China, Bulgaria has to enhance R\&D, attract more Chinese investments, and work on better absorption EU funds.
\end{abstract}

\section{Introduction}

Ever since the fall of the Bulgarian communist party regime in 1989, the country has been going through a series of political, economic and sociological changes. In 2007, Bulgaria joined the European Union, which gave the local economy a strong boost. As a part of the promoted by EU economic integration, the country entered The Single market and it started implementing the common for all EU member states trade policies. After 2007, the bilateral relations with China progressed rapidly, which help to further strengthen Bulgaria's role as a bridge between East and West and a gateway to the European market.

\section{Literature Review}

China and Bulgaria traditionally have a long-lasting partnership, which is only going to strengthen in time (Zhang Wanxue, 2009). The relationship between the both countries has undergone a rapid development after 2005 and this trend is going to continue in the future (Angel Orbetzov, 2012). The positive trend in trade between both countries, reached its peak in 2012, and came to a sudden fall in 2013 due to the Global Financial crisis (Nikolov, Kyoseva, Toptanova, 2013). As it can be seen from Tables 1 and 2, China has been ranked as one of Bulgaria's the top 10 trade partners for 2013-2014. According to the data, China took ninth place both among Bulgaria's largest import partners (766.75 mln eur) and its biggest export destinations (650.94 mln eur). It is easy to notice that after 2007, exports have been increasing and Bulgaria's trade deficit with China has been reducing until 2014. 
The Bulgarian companies are focused strongly on exporting goods to China, (Malinova, 2015). According to Malinova, there are three main reasons for the positive development in Sino-Bulgarian economic relationship: (1) Chinese government's strategy for balancing the export-import, focusing on imports to China. (2) Peking actively encouraging the local consumption premising deepening of bilateral relationship. (3) The newly formed middle class in China is getting richer; also the standard of living in the country is constantly rising, which increases the domestic demand for European goods.

Table 1 Bulgaria's top 10 trade partners for 2013 - 2014 (in mln. eur)

\begin{tabular}{|l|l|l|l|l|l|}
\hline Export & & \multicolumn{5}{|l|}{ Import } \\
\hline $\begin{array}{l}\text { Partner } \\
\text { country }\end{array}$ & 2013 & 2014 & $\begin{array}{l}\text { Partner } \\
\text { country }\end{array}$ & 2013 & 2014 \\
\hline Germany & 2740.12 & 2656.21 & Russia & 4780.09 & 3976.85 \\
\hline Turkey & 2003.27 & 2072.21 & Germany & 2792.41 & 3206.11 \\
\hline Italy & 1924.41 & 1979.46 & Italy & 1920.63 & 1838.81 \\
\hline Romania & 1719.27 & 1748.61 & Romania & 1719.78 & 1782.75 \\
\hline Greece & 1545.31 & 1480.15 & Turkey & 1509.63 & 1481.78 \\
\hline France & 959.68 & 947.56 & Greece & 1434.76 & 1336.18 \\
\hline Belgium & 642.36 & 917.97 & Spain & 1344.51 & 1279.4 \\
\hline Singapore & 332.04 & 567.08 & Hungary & 784.94 & 881.54 \\
\hline China & 650.94 & 533.24 & China & 766.75 & 864.57 \\
\hline Russia & 582.61 & 527.57 & France & 767.52 & 793.12 \\
\hline
\end{tabular}

Source: Bulgarian Statistical Reference Book 2015

Table 2 Trade between Bulgaria and China (in mln. eur)

\begin{tabular}{|l|l|l|l|l|}
\hline Year & $\begin{array}{l}\text { Bulgaria } \\
\text { export to } \\
\text { China }\end{array}$ & $\begin{array}{l}\text { China import } \\
\text { to Bulgaria }\end{array}$ & Total & Balance \\
\hline 2006 & 39.86 & 491.13 & 531 & -451.27 \\
\hline 2007 & 51.98 & 425.51 & 477.49 & -373.54 \\
\hline 2008 & 80.39 & 567.54 & 647.93 & -487.15 \\
\hline 2009 & 69.91 & 321.15 & 391.07 & -251.24 \\
\hline 2010 & 127.77 & 334.13 & 461.9 & -206.37 \\
\hline 2011 & 206.83 & 481.83 & 688.66 & -275 \\
\hline 2012 & 389.18 & 499.31 & 888.49 & -110.13 \\
\hline 2013 & 443.66 & 521.39 & 965.04 & -77.73 \\
\hline 2014 & 533.24 & 864.57 & 1397.81 & -331.32 \\
\hline
\end{tabular}

Source: Bulgarian Statistical Reference Book 2015

With export potential and a wider presence in the Chinese market are goods which are traditional for Bulgaria and it is known in the markets in Asia, such as Bulgarian wine, dairy products, oils and especially rose oil production, machine products of the chemical industry (Nanova N., Dimitrov L., 2012). According to Victor Azmanov, the increasing of Chinese investments in Bulgaria in the recent years is due to China's increasing interest in the Central and Eastern European countries. (Azmanov V., 2012) Through the launched in 2012 " $16+1$ " platform between China and 16 Central and Eastern European countries, China's leaders hope to increase exports, expand transport connections and get an easier access to the vast European market.

There isn't an extensive study on Bulgaria-China competitiveness index. The studies focus on EU-China competitiveness. Maria Silgoner, Katharina Steiner, Julia Wörz and Christian Schitter study the competitiveness of China-EU15 trade in comparison to that 
of CESEE-EU15. According to them, the competition between China and the Countries from Central Europe in the EU-15 market has been increasing. Both the CESEE region and China could intensify existing trade linkages particularly due to their strong competitiveness. They could improve their competitive position further by responding more aptly to demand characteristics (Maria Silgoner, Katharina Steiner, Julia Wörz and Christian Schitter, 2013).

\section{Analysis of the Elements Influencing Bulgari-China Trade Competitiveness Index Before and After Bulgaria Joining the EU}

This study aims to determine the factors influencing Bulgaria-China's TCI and also what effect the former's accession to the EU has on them. We chose to analyze the time span from 1996-2014 because of the following three events: (1) In 1996-1997 Bulgaria went through which resulted in the government's bankruptcy; (2) In January 2007, Bulgaria officially joined the EU;(3) The global financial crisis of 2008-2009 which led to an increasing government's debt and a high unemployment rate in Bulgaria.

\section{Trade Competitiveness Index}

The trade competitiveness index (TCI) is a measurement of the competitiveness of the bilateral trade between two partnering countries. We obtained the TCI of Bulgaria-China for several groups manufactured goods (see Table 4) using the following formula:

$$
T C I_{\tilde{i}}^{k}=\frac{X_{\tilde{i}}-M_{\tilde{i}}}{X_{\tilde{i}}+M_{\tilde{i}}} \text {. }
$$

Where: $X$ is the export from Bulgaria to China for a $i$ year of a $k$ group of goods and $M$ is the import from China to Bulgaria year of a $k$ group of goods for the year $i$;

\section{OLS Model to Determine the Factors Influencing Bulgaria-China's TCI}

For the purposes of this study we propose an OLS model through which to identify what elements influence Bulgaria-China trade competitiveness index (TCI) for several groups manufactured goods and how Bulgaria's accession to the European Union affected them:

$$
T C I_{i \mathrm{i}}^{k}=\beta_{0}+\beta_{1} \mathrm{X}_{1 \mathrm{i}}+\beta_{2} \mathrm{X}_{1} \text { dummy }+\mathrm{u}_{\mathrm{i}}, \mathrm{i}=1,2, \ldots, \mathrm{n} .
$$

Where: TCI is Bulgaria-China's trade competitiveness index (TCI) of k group of goods for an $\mathrm{i}$ year, $\mathrm{X}_{1}$ is an economic measurement of the Bulgarian economy (Gross domestic product (GDP), Foreign direct investment (FDI), Bulgaria's inflation rate (IR), Lev/RMB exchange rate (EXR), Bulgarian balance of payment (BOP); Currency reserves (RES)). We use a dummy variable dummy to represent the country's accession to the EU (0 for the time before 2007 and 1 after 2007). 
Table 3 Trade competitiveness index

\begin{tabular}{|c|c|c|c|c|c|c|c|c|c|}
\hline Year & $\begin{array}{l}\text { Trade in } \\
\text { goods } \\
\text { and } \\
\text { services }\end{array}$ & $\begin{array}{l}\text { Total all } \\
\text { products }\end{array}$ & $\begin{array}{l}\text { Primary } \\
\text { commodities, } \\
\text { precious } \\
\text { stones and } \\
\text { non-monetary } \\
\text { gold (SITC } 0 \\
+1+2+3+ \\
4+68+667+ \\
971) \\
\end{array}$ & $\begin{array}{l}\text { Manufactu } \\
\text { red goods } \\
\text { (SITC } 5 \text { to } \\
8 \text { less } 667 \\
\text { and } 68 \text { ) }\end{array}$ & $\begin{array}{l}\text { Labour- } \\
\text { intensive } \\
\text { and } \\
\text { resource- } \\
\text { intensive } \\
\text { manufacture } \\
\mathrm{s}\end{array}$ & $\begin{array}{l}\text { Low-skill and } \\
\text { technology- } \\
\text { intensive } \\
\text { manufactures }\end{array}$ & $\begin{array}{l}\text { Medium-skill } \\
\text { and } \\
\text { technology- } \\
\text { intensive } \\
\text { manufactures }\end{array}$ & $\begin{array}{l}\text { High-skill } \\
\text { and } \\
\text { technology- } \\
\text { intensive } \\
\text { manufacture } \\
\text { s }\end{array}$ & $\begin{array}{l}\text { Manufac } \\
\text { tured } \\
\text { goods }\end{array}$ \\
\hline 1996 & 0.2050 & 0.1959 & -0.3869 & 0.2628 & -0.9303 & 0.7963 & -0.4194 & 0.3343 & 0.6659 \\
\hline 1997 & -0.1493 & 0.2050 & -0.3798 & 0.2718 & -0.9286 & 0.8001 & -0.4108 & 0.3422 & 0.6720 \\
\hline 1998 & -0.682 & -0.1493 & -0.9153 & 0.0820 & -0.9232 & -0.9964 & -0.9102 & 0.3278 & -0.9040 \\
\hline 1999 & -0.7788 & -0.6820 & -0.7614 & -0.6517 & -0.9467 & -0.3116 & -0.9844 & -0.5263 & -0.4688 \\
\hline 2000 & -0.7233 & -0.7788 & -0.6170 & -0.8205 & $\begin{array}{l}-0.8899 \\
\end{array}$ & -0.3184 & -0.9513 & -0.8597 & -0.3388 \\
\hline 2001 & -0.8001 & -0.7232 & -0.1305 & -0.8770 & -0.9580 & -0.8800 & -0.9270 & -0.8183 & -0.9490 \\
\hline 2002 & -0.8323 & -0.8001 & -0.2361 & -0.9422 & -0.9873 & -0.7943 & -0.9556 & -0.9485 & -0.9791 \\
\hline 2003 & -0.6409 & -0.8323 & -0.0754 & -0.9207 & $\begin{array}{l}-0.9888 \\
\end{array}$ & -0.7670 & -0.8628 & -0.9675 & -0.8283 \\
\hline 2004 & -0.8534 & -0.6413 & -0.0577 & -0.7063 & -0.9831 & 0.1891 & -0.8549 & -0.9507 & 0.1802 \\
\hline 2005 & -0.8161 & -0.8534 & -0.2669 & -0.8852 & -0.986 & -0.3389 & -0.9301 & -0.9671 & -0.5240 \\
\hline 2006 & -0.8505 & -0.8161 & 0.2069 & -0.8897 & -0.9891 & -0.2510 & $\begin{array}{l}-0.9593 \\
\end{array}$ & -0.9709 & -0.3581 \\
\hline 2007 & -0.8771 & -0.8505 & 0.1770 & -0.9434 & -0.9653 & -0.9648 & -0.8836 & -0.9652 & -0.7417 \\
\hline 2008 & -0.8475 & -0.8771 & 0.0218 & -0.9666 & -0.9789 & -0.9940 & -0.9547 & -0.9629 & -0.7927 \\
\hline 2009 & -0.7753 & -0.8475 & 0.3547 & -0.9755 & -0.9850 & -0.9955 & -0.9721 & -0.9675 & -0.5489 \\
\hline 2010 & -0.4462 & -0.7753 & 0.4529 & -0.9625 & -0.9707 & -0.9911 & -0.9514 & -0.9606 & -0.4793 \\
\hline 2011 & -0.3981 & -0.4462 & 0.6697 & -0.8685 & -0.9239 & $\begin{array}{l}-0.9979 \\
\end{array}$ & -0.8440 & -0.8001 & 0.0423 \\
\hline 2012 & -0.1210 & -0.3981 & 0.6369 & -0.9081 & -0.9323 & -0.9921 & -0.8972 & -0.8744 & 0.1980 \\
\hline 2013 & -0.0844 & -0.1210 & 0.8449 & -0.8776 & -0.8279 & -0.9814 & -0.8830 & -0.8622 & 0.5570 \\
\hline 2014 & -0.2362 & -0.0844 & 0.8548 & -0.8289 & -0.8019 & $\begin{array}{l}-0.9796 \\
\end{array}$ & -0.8254 & -0.7698 & 0.4435 \\
\hline
\end{tabular}

Source: OECD database

\section{Data Sources}

TCI is calculated based on the bilateral trade and the export data of 1996-2014 bilateral trade data, and the corresponding calculation downloaded on the OECD website. This paper also uses the United Nations commodity Trade Statistics database data (SITC Rev.4), which divide all trade goods into nine categories, namely 0-4 class for Primary products, 5-9 class for Industrial products. Data of Bulgarian GDP, inflation rate, BGN / RMB exchange rate were obtained from the World Bank's website.

TCI is Bulgaria and Chinese trade competitiveness index for goods and services, calculated by formula (1); TCI $^{2}$ is TCI for Manufactured goods (SITC 5 to 8 less 667 and 68) calculated by formula (1), $\mathrm{TCI}^{3}$ is TCI for Low-skill and technology-intensive manufactures calculated by formula (1), $\mathrm{TCI}^{4}$ is TCI for Medium-skill and technology-intensive manufactures calculated by formula (1), $\mathrm{TCI}^{5}$ is TCI for High-skill and technology-intensive manufactures calculated by formula (1), $\mathrm{TCI}^{6}$ is TCI for Manufactured goods; GDP is Bulgaria's GDP (data source: World Bank database), FDI is Foreign direct investment in Bulgaria (data source: World Bank database); IR is the Bulgarian inflation rate (data source World Bank database); EXR is Lev/RMB exchange rate(data source: WorldBank database); BOP is Bulgaria's balance of payment (data source: World Bank database); RES is the Bulgarian currency reserves (data source: World Bank database).

\section{Results}

The following results are the results from the conducted regression (Table 4):

(1) Bulgaria's FDI has an inhibitory effect on the TCI. For every increased unit foreign investments, TCI decreased by 0.17147 . Bulgaria FDI also has a negative impact on $\mathrm{TCI}^{2}$. 
(2) Exchange rate has a promoting effect on TCI. From table 3 we can see, with every unit the LEV/RMB exchange rate increase, TCI increases with 0.262611. It also has a promoting effect on TCI for Manufactured goods (SITC 5 to 8 less 667 and 68). This shows that the stability of the LEV/RMB exchange rate strengthens the trade competitiveness index for Bulgaria and China.

(3) BOP also has a positive effect on the TCI. A unit increase BOP generate an increase in the competitiveness index of 0.262611. At the same time, an increase of BOP results in 0.19748 of TCI of Manufactured goods.

(4) Bulgaria's inflation rate (IR) has a promotion effect on the Trade competitiveness index of Low-skill and technology-intensive manufactures, Medium-skill and technology-intensive manufactures, High-skill and technology-intensive manufactures by $0.045444,0.1929,0.159677$ and 0.150619 respectively.

(5) After Bulgaria's accession to the European Union, Bulgaria's currency reserves affect positively the trade competitiveness index. Each unit of higher Currency reserves, generate an increase of the trade competitiveness index of 0.17274 .

(6) After Bulgaria joining the EU, the country's GDP has a promotion effect on the Trade competitiveness index of 0.127641 per unit.

Table 4: OLS Results

\begin{tabular}{|l|l|l|l|l|l|l|}
\hline Y & \multicolumn{1}{|c|}{ Estimate1 } & Estimate2 & Estimate3 & Estimate4 & Estimate5 & Estimate6 \\
\hline BOP & $0.170717^{* * *}$ & & & & & $0.19748^{* * *}$ \\
\hline EXR & $0.262611^{* * *}$ & $0.262611^{* * *}$ & $0.402672^{* * *}$ & $0.117429^{* * *}$ & & 0.311551 \\
\hline FDI & $-0.17147^{* * *}$ & $-0.23248^{* * *}$ & & $-0.06827^{* * *}$ & $-0.2786^{* * *}$ & \\
\hline DUMMY*RES & 0.17274 & & & & & \\
\hline & & & & & - & \\
GDP & & $-0.58123^{* * *}$ & & & & \\
\hline IR & & $0.150619^{* * *}$ & & & & \\
\hline Dummy*IR & & $-0.10482^{* * *}$ & $-0.18144^{* * *}$ & & & \\
\hline R2 & 0.532562 & 0.691292 & 0.676392 & 0.559139 & 0.587614 & 0.292608 \\
\hline F-stat & 11.25389 & 21.15378 & 19.81144 & 12.41462 & 4.863594 & 2.392418 \\
\hline
\end{tabular}

$10 \% *, 5 \% * *, 1 \% * * *$

\section{Implications}

Bulgaria is a very small economy, highly dependent on major market participants. After the crisis in 1996, the Bulgarian Lev has been pegged, first to the Deutsche mark, and later to the Euro, guaranteeing it stability, as well as being the strongest and most stable currency in Eastern Europe. This aided the development of Chinese-Bulgarian trade, stimulating import from China. In the same time, the drastic decrease in the exchange rate of the euro, influenced by the Greek and Cyprus's debt crises, negatively affected the Chinese-Bulgarian trade competitiveness by deflating both exports and imports which is a clear sign of Bulgaria's and other CEE's dependence of the EU. Bulgaria needs to take measures to further develop the manufacturing sector, paying special attention to Medium-skill and High-skill manufactures. There need to be made improvements for more effective $\mathrm{R} \& \mathrm{D}$, as well as for increasing productivity. This will be beneficial for attracting more Chinese investments who want to enter the European market, in the country. A good example for this is the Chinese automobile company Great wall, which jointly with the local Litex Motors manufactures cars in Bulgaria and then exports them to other European countries. At the moment, the biggest investments in Bulgaria belong to other European countries such as Netherlands and Germany, which promotes expanding on the trade with the European countries, on the expense of 
the trade with non-European countries such as China. Western European countries are also a preferred destination for outward Bulgarian investments. Increased Chinese FDI in the country will aid the development of the bilateral trade between Bulgaria and China. There is a potential growth, especially in the food and beverages sector, also car and machine manufacturing. Bulgaria should follow the example of countries like Poland, who successfully managed to develop better trade relationship with China.

On other hand, the unstable economic situation in Bulgaria poses a serious threat to the Chinese-Bulgarian trade. The slow temps of economic growth, prevents the trade from expanding. The strict government fiscal reforms and raising unemployment rate hit the import sector and deflated the export to china.

Lastly, Bulgaria's accession to the EU, has a limited influence on the Chinese-Bulgarian trade competitiveness and hasn't produced the so desired positive effect on Chinese-Bulgarian trade. Bulgaria has to make reforms in order to absorb European funds more effectively and develop the country's exporting sector.

\section{References}

[1] Azmanov V., "Chinese investments in Bulgaria increasing".Available from: http://www.bulgariachina.com/bg/news/view/14.kitaiskite-investicii-v-balgariya-she-s e-uvelichavat.html, 2012

[2] Malinova M., "Current situation and perspectives of Bulgarian-Chinese relations", Available from: http: // www. geopolitica. eu/ spisanie- geopolitika- broi-2-2015/1761sastoyanie-i-perspektivi-za-razvitie-na-balgarsko-kitayskite-otnosheniya,\%20, 2015

[3] Nanova N., Dimitrov L., "China", Available from: http:// export. government. bg/ ianmsp/Komunic_STIV/business_compas/China-bussines-compas-2012, 2012

[4] Nikolov, Kyoseva, Toptanova, "China". Available from: http: //www. mi. government.bg/bg/themes/kitai-192-333.html?p=eyJwYWdlljoOfQ==, 2012

[5] Orbetzov, Angel, "Diplomatic relationship between China and Bulgaria". Available from: http://mychinesenow.com/otnosheniya-kitai-balgaria.html, 2012

[6] Silgoner, Maria \& Steiner, Katharina \& Wörz, Julia \& Schitter, Christian2013, "Fishing in the same pool? Export strengths and competitiveness of China and CESEE in the EU-15 Market," Working Paper Series1559, European Central Bank, 2013

[7] Zhang,Wanxue, "Chinese reform and openning to the world". Available from: http://mychinesenow.com/otnosheniya-kitai-balgaria.html, 2012 